\title{
Ser e parecer: indumentária e hierarquia social na sátira de frei Lucas de Santa Catarina, Portugal, século XVIII
}

Being and appearing: clothing and social hierarchy in the satire of Frei Lucas de Santa Catarina (Portugal, 18th century)

1. Graduada em História pela Universidade Estadual de Campinas (Unicamp). Mestra e doutora em História pela Unicamp, na área de política, cultura e memória. E-mail: $<$ lucipdg@gmail.com>.

RESUMO: A partir da perspectiva analítica da cultura material investigaremos a valorização das aparências na sociedade portuguesa da primeira metade do século XVIII, examinando representações do vestir e do aparentar na literatura de cordel produzida por frei Lucas de Santa Catarina. Trata-se de observar alguns aspectos das relações entre aparências e comportamentos na construção de uma sátira que visava criticar a falta de correspondência entre ser e parecer, num contexto em que a mobilidade social despontava em diversos setores. Tais textos fornecem ao historiador um amplo quadro no qual indumentária e comportamentos são descritos de maneira imbricada nas rotinas cotidianas. A partir dessas descrições, observaremos os conjuntos de artefatos necessários ao cuidado da imagem a ser apresentada no meio social, analisando seus usos e a percepção deles transcritos nas fontes selecionadas. Assim, refletiremos sobre alguns dos embates acerca das vestimentas e das modas, que se fundamentavam na contestação da ascensão social e no esforço de conter um amplo processo de mudança que marcava a sociedade portuguesa do período.

PALAVRAS-CHAVE: Cultura Material. Aparência. Hierarquia Social. 
ABSTRACT: From the analytical perspective of material culture, this article will investigate the valuation of appearances in Portuguese society in the first half of the 18th century, through the examination of representations of clothing and appearance in the cordel literature produced by Frei Lucas de Santa Catarina. The objective is to observe some aspects of the relationships between appearances and behaviors in the construction of a satire that aimed to criticize the non-correspondence between being and appearing, in a context of emerging social mobility for several sectors. Such texts provide historians with a broad framework where clothing and behavior are described amid everyday routines. From these descriptions, we will observe the sets of artifacts necessary to care for the image to be presented in social environments, analyzing its uses and the perception of these transcripts in the selected sources. Thus, we will reflect on some of the clashes over clothing and fashion trends that were based on the challenge of social ascension and the effort to contain a broad process of change that marked the Portuguese society of the period.

KEYWORDS: Material Culture. Appearance. Social Hierarchy. 
A cultura material é um dos principais informantes de como as pessoas viviam outrora. Por meio dos elementos materiais que circundavam os sujeitos em suas vivências cotidianas é possível conhecer estilos de vida que variavam conforme diferentes níveis de riqueza e posições sociais, bem como pensar nos significados da posse e do uso de objetos. Capturátos em fontes escritas é sempre um desafio: a cultura material por vezes é abundantemente representada em documentos de natureza cartorária, dentre os quais os inventários post mortem são amplamente utilizados nas pesquisas históricas devotadas ao consumo, cotidiano e espaço doméstico, entre outros. Todavia, as maneiras como seus elementos eram empregados nas rotinas do dia a dia permanecem obscuras, bem como as representações que incidiam sobre determinados objetos, ou mesmo a maneira como eram percebidos nas dinâmicas das relações sociais. Nesse sentido, fontes de caráter mais descritivo, como a literatura, são um campo fértil a ser explorado por estudos que se dediquem a investigar as práticas e representações vinculadas aos elementos materiais da cultura.

Nesse sentido, a literatura de cordel portuguesa do século XVIII dispõe de um amplo potencial, sobretudo para os estudos que buscam compreender aspectos da indumentária, seus usos, significados e a influência das modas nesse segmento da cultura material. Isso ocorre porque tais temas eram comumente destacados nessa produção por meio de figuras estereotipadas, fundamentadas em defeitos e vícios, cujos comportamentos sociais relativos ao aparentar eram satirizados. ${ }^{2}$

As interações sociais e suas representações culturais integram, nos quadros de uma história do cotidiano, uma das tensões características da modernidade: aquela entre o ser e o parecer, relação que deve ser destacada na análise de práticas e mecanismos de transmissão de gostos, modas, padrões de conduta e símbolos de ascendência social. ${ }^{3}$ Essa tensão imanente à aparência, como prática cultural cotidiana, sugere a complexidade da realidade à qual pertenceu. Mesmo que pareçam equivocadas, tais representações integravam aquela realidade, premeditadas e condicionadas "por factores subjetivos que conforman, a su vez, el mundo objetivo de lo cotidiano". ${ }^{4}$ Tal tensão marcou de maneira profunda o conjunto de relações que os sujeitos estabeleciam com a cultura material ao seu redor, especialmente as vestimentas.

A cultura material, como "complexo e dinâmico repertório do que os homens são capazes de produzir, fazer circular e consumir", sinaliza as funcionalidades da criação humana e denota "os diferentes significados atribuídos
2. Conforme define Susana Cabete, o estereótipo seria uma forma redutora da imagem, rígida e fixa, assentada na "estabilidade dos conceitos e práticas partilhados pela sociedade", que deriva "das crenças e ideia pré-concebidas sobre o outro". Como forma caricatural e deturpada da realidade, o estereótipo corresponde a "uma forma mínima de comunicação, uma expressão emblemática de uma cultura e de um sistema ideológico. Não sendo polissémico, é policontextual e susceptível de ser sempre utilizado e, implicitamente, impõe uma hierarquia entre mundos e culturas" (CABETE, 2010, p. 98).

3. Cotidiano compreendido como um lento transcorrer da vida diária, sob uma aparência de imobilidade resguardada pela repetição de formatos estabelecidos, no qual se produziam constantes mudanças como consequência de insatisfações ou conflitos. O desafio de uma história do cotidiano consistiria justamente em perceber na documentação essa dinâmica velada (PEÑA DÍAZ, 2012, p. 6).

4. Ibid., p. 11. Grifo original. 
5. Meneses (2011, p. 398).

6. Cf. Meneses (1983, 2007).

7. Id., 2008, p. 12.

8. Miller (2013, p. 22-23).

9. Silva (2019).

10. Sennett (2014, p. 106).

11. Sobre como as marcas físicas interferiam na leitura que a sociedade poderia fazer da aparência dos sujeitos na América portuguesa no século XVIII, conferir Lara (2007). a um dado artefato por uma comunidade e/ou sociedade ao longo do tempo". ${ }^{5}$ Resultantes de formas de organização do homem em sociedade, os artefatos criam condições para produzir e efetivar relações sociais, e se encontram imbricados nas mais diversas formas de interação social. ${ }^{6}$ Eles expressam, moldam e constituem os sujeitos em diversas gradações.? Em muitos aspectos, as coisas criam os seres. Nessa perspectiva, a indumentária não é algo superficial, pois as roupas "são o que faz de nós o que pensamos ser". ${ }^{8}$

Vestimentas e adereços eram importantes nas sociedades de Antigo Regime. As aparências viabilizavam certos comportamentos sociais pertinentes às civilidades e, simultaneamente, reforçavam a instabilidade das hierarquias sociais em seus segmentos visuais, criando confusão acerca do lugar de cada um na sociedade. ${ }^{9}$ Richard Sennett, ao analisar a ascensão do universo privado a partir dos casos de Londres e Paris no século XVIII, afirmou que o vestuário de passeio tinha por propósito "tornar possível às outras pessoas agirem como se soubessem quem se era". ${ }^{10}$ A roupa não assegurava conhecer aquele com quem se tratava, mas permitia que as pessoas se comportassem como se estivessem seguras em relação a esse conjunto de informações. A assertiva é plausivel também para o reino e para as diversas regiões do Império Português no mesmo período, resguardadas suas especificidades. Escolher o que vestir era, na maior parte do tempo, algo devotado à exterioridade, à leitura que os outros fariam de si e ao atendimento das expectativas alheias, com o objetivo de aguçar nos outros um sentimento de admiração e viabilizar uma série de comportamentos fundamentados nas hierarquias sociais. Ou seja, uma cadeia de gestos por meio dos quais se efetuavam as sociabilidades e o relacionamento social dependiam da leitura inicial que os indivíduos faziam a partir das aparências, constituídas sobretudo na articulação de diversos artefatos indumentários, bem como das marcas físicas. ${ }^{11}$

Se por um lado a aparência permitia a identificação dos sujeitos com sua condição social, ou estado, por outro, a dinâmica social era muito mais complexa do que uma estrutura social tripartida poderia abarcar. Transformações econômicas possibilitavam o enriquecimento e, por vezes, a mobilidade social. Mas, antes de concretizar essa troca de estado, o acúmulo de riquezas proporcionava aos sujeitos e a suas famílias o refinamento dos modos. Um conjunto de mudanças de ordem material e comportamental impactava no preenchimento de interiores domésticos, assim como nos transportes e vestimentas ostentados nos espaços públicos. A nova condição econômica viabilizava a exibição de um posicionamento desejado na estrutura social, mas nem sempre conquistado. Nesse sentido, estava posta a tensão entre o ser e o parecer, amplamente representada na literatura de cordel portuguesa que circulou intensamente ao longo do século XVIII. 
Neste artigo serão trabalhados, a partir de exemplares dessa produção literária nos quais os temas da moda e das vestimentas foram tratados, alguns traços materiais pertinentes à aparência dos sujeitos. Examinando a representação do vestir e do aparentar na literatura de cordel produzida por Frei Lucas de Santa Catarina, observaremos alguns aspectos das relações entre aparências e comportamentos na construção de uma sátira que visava criticar a não correspondência entre o ser e o parecer, num contexto em que a mobilidade social despontava em diversos setores. Extensamente representado por meio de estereótipos, o aspecto exterior dos sujeitos descritos nesses textos permite avaliar a incorporação dos modelos desejados, em termos de elegância e aparência distintiva, e as críticas incidentes sobre esse processo, compreendido como dissimulação pelos setores mais conservadores da sociedade. Os estereótipos criados na literatura de cordel revelam como o conjunto das vestimentas e dos gestos eram usados e percebidos em diferentes setores sociais. Tais textos fornecem ao historiador um amplo quadro no qual vestimentas e comportamentos são descritos de maneira imbricada na dinâmica das rotinas cotidianas, destacando os artefatos em seu emprego sobre o corpo. Além de elucidar alguns dos objetos utilizados nas rotinas diárias ligadas aos cuidados com a aparência, esse conjunto de textos constitui um caminho profícuo para refletir sobre os usos e as diferentes percepções das aparências na sociedade em questão. A partir dessas descrições, observaremos traços dos conjuntos de artefatos necessários ao cuidado da imagem a ser apresentada no meio social, analisando os usos e a percepção sobre eles registrados nas fontes selecionadas. Assim, refletiremos sobre alguns dos embates acerca das vestimentas e das modas que se fundamentavam na contestação da ascensão social de sujeitos de estratos inferiores e no esforço de conter um amplo processo de mudança que marcava a sociedade portuguesa do período.

\section{HIERARQUIA, MOBILIDADE SOCIAL E HONESTIDADE}

Mais do que parece, a moda foi, ao longo da modernidade, um assunto interessante para um amplo grupo de pessoas. Mesmo que inventada e seguida nos setores sociais mais ricos, no que se referia ao trajar, o acesso à riqueza e/ou ao crédito possibilitava melhorias significativas na aparência dos sujeitos. ${ }^{12}$ Seguir as constantes mudanças que ela impunha exigia amplos cabedais: a renovação periódica do vestuário era inacessível à maior parte da sociedade lusa, parcela à qual cabia observar e admirar aqueles que possuíam o necessário à exibição nos
12. Ao estudar as tendas dos mercadores têxteis portugueses a partir dos inventários realizados em processos inquisitoriais dos séculos XVII e XVIII, Isabel Drumond Braga afirmou que "No que se refere ao trato, pode afirmar-se que, não sendo o dinheiro o principal indicador do status durante a Época Moderna, a sua presença não deixava de ser relevante, até porque permitia a aquisição de elementos importantes na definição de certos estatutos". Ademais, a autora mostra a diversidade de produtos, sobretudo têxteis, disponíveis em lojas espalhadas por todo o reino (BRAGA, 2017, p. 188). 
13. Joaquim Romero Magalhães, ao tratar dos nobres da governança das terras, descritos por Raphael Bluteau como "Estado do meio", observa que entre as formas de distinção praticadas por esse grupo social estavam o trato da pessoa, o andar a cavalo, o servir-se de criados, o portar símbolos de autoridade que demonstrassem os cargos ocupados na governança da terra e o viver à lei da nobreza, sem trabalhar, apresentando-se em público em procissões, aclamações e cerimônias, entre outros. "Este aparecer e parecer é fundamental para a definição de uma posição social que se afirma e que se respeita" (MAGALHÂES, 2005, p. 67).

14. Roche (2007) e Giorgi (2017).

15. Segundo Isabel Drumond Braga, "a posse de bens móveis e imóveis indiciava o lugar de cada um na sociedade. [...] tanto a casa como o recheio, a par do vestuário e dos adereços de seus moradores, constituíam valores simbólicos mediante os quais se afirmava a consideração social. Na época, esses sinais exteriores de reconhecimento do status passavam pela posse de terras e casas, mas também de mobiliário, cavalos, coches, serviçais, entre os quais escravos, vestuário de seda, joias pratas e porcelanas, na medida em que a posse e a exibição dos bens serviam para comunicar o estatuto" (BRAGA, 2009, p. 144).

16. De acordo com Andrea Durães "ao nível das representações e dos discursos oficiais, no período moderno, destaca-se a longevidade do modelo trinitário, assente na concepção corporativa e organicista da sociedade, que tinha como referência o modelo medieval da tripartição social estruturador da sociedade. Numa sociedade espaços públicos. À tal conjuntura se somava a grande importância dada às aparências na época em questão. ${ }^{13}$

Conforme demonstrou Daniel Roche, na França do mesmo período uma cultura das aparências se formava, fundamentada na definição da imagem como um dos elementos referenciais do prestígio pessoal e social. A indumentária e sua ostentação eram consequências da representação social, integrando o conjunto dos comportamentos cotidianos. Esse protocolo estético logo se firmaria em outras regiões, como a Espanha. ${ }^{14}$ Em Portugal, de maneira semelhante, a aparência recebia grande valorização no meio social. $\bigcirc$ aparentar desempenhava funções diversas nos mecanismos de diferenciação e impactava no relacionamento social. ${ }^{15}$ Desta maneira, as vestimentas integravam estratégias de ascensão social. Justamente por essa importância, a percepção das aparências variava. Se para uns era um meio de se tornar mais digno, para outros significava embuste e desonestidade. Isso se devia aos lugares ocupados na estrutura social pelo observador e pelo observado, que ensejavam o desejo de ascensão ou de manutenção dessas posições, o que, por sua vez, modelava a relação de ambos para com os estratos logo acima e logo abaixo deles.

Durante a Modernidade a sociedade portuguesa, do ponto de vista legal, estava dividida em ordens, sendo trinitária e trifuncional. Todavia, tal concepção, marcadamente presente no pensamento de juristas e políticos do período, não traduzia a realidade da época. Consequentemente, a complexidade da organização social se refletia na multiplicidade de discursos sobre o espectro social, que tornavam cada vez mais evidente a inadequação de um discurso oficial. ${ }^{16}$ Andrea Durães, ao analisar discursos de naturezas diversas para conhecer - que se concebia por camadas intermédias em Portugal, entre 1600 e 1850, constatou que a palavra estado abarcava múltiplos significados: "uma categoria social semelhante à de ordem; um estatuto social, um grau de prestígio e honorabilidade; [...] um ofício, ocupação ou profissão, ou ainda um grau de disponibilidade econômica, apreensíveis a partir do nível de riqueza ou estilos de vida". ${ }^{17} \mathrm{Em}$ cada uma das acepções identificadas pela autora, com exceção da primeira, a configuração e hierarquização da sociedade diferia daquela imposta pelas ordens. Assim, o vocabulário social pluralizado indicava a diversidade de interpretações sobre a organização da sociedade lusa que existiam paralelamente àquela defendida na legislação e no discurso oficial, pluralidade que também se relacionava às mudanças na conjuntura vivenciadas no período.

Desde a baixa medievalidade transformações econômicas abriram espaço para mudanças nas fontes e na natureza da riqueza: separada do fundo territorial, agrário e senhorial, a riqueza passou a estar mais atrelada às atividades comerciais 
praticadas pelos estratos urbanos, deixando de corresponder aos estratos privilegiados tradicionais. A dinâmica do capitalismo mercantil impactou as estruturas da sociedade lusa, alterando posicionamentos e dificultando o ordenamento social à medida que essa nova riqueza adquiria poder social. ${ }^{18}$

Nesse período se multiplicaram os meios de ascensão social. Por todo Portugal existiam grupos intermédios ligados à administração das casas das grandes famílias terratenentes e ao cotidiano dos episcopados, ordens e congregações. Os homens de negócios, concentrados mormente nas regiões portuárias com vocação transatlântica, enfrentavam, em seu processo de ascensão, resistências diversas, de naturezas religiosas, culturais e políticas, apesar de certas empresas comerciais receberem financiamento de fidalgos, mosteiros e da própria Coroa. $\bigcirc$ exercício das letras, em particular os ofícios de escrita, passavam por um processo acentuado de dignificação social. No século XVIII o reconhecimento das atividades dos comerciantes de grosso trato era estimulado num processo que foi legalmente consolidado sob o reinado de D. José, que aumentou, também, o fomento das manufaturas. "Todo um conjunto de indivíduos de extração mediana conquista, assim, o direito a um lugar efetivo entre os privilegiados, e carrega consigo, em movimento ascensional, uma série de outros agentes inferiores" ${ }^{19}$

$\bigcirc$ estado do meio, integrado pelos grandes comerciantes, entre outros personagens, passava por um processo de ascensão traduzido em bem-estar proporcionado pela riqueza, que possibilitava o culto do luxo. Este exercia efeitos na importação de bens de consumo supérfluo, bem como no desenvolvimento de manufaturas nacionais de produção de tais bens. Os usos e costumes se refinavam no vestir e nas aparências em geral. ${ }^{20}$

Em Portugal, durante o Antigo Regime, enriquecer ou empobrecer não constituía "um fato social decisivo, do ponto de vista da categorização". Ou seja, a riqueza em si não era um fator decisivo de mudança social. A mudança rápida e notória era algo extraordinário e dependia do poder régio. Ademais, esta não era esperada e, tampouco, desejada: "mudança e confusão de estados são, para o homem moderno, sinais de perturbação social e de convulsão da ordem política". ${ }^{21}$ Mudar de posicionamento na sociedade lusa moderna deveria ser um processo natural, com seus trâmites, efeitos e tempo esperados. Não existiria mobilidade legítima, autêntica e honesta fora de um modelo de desenvolvimento da natureza pelo tempo. A riqueza daria claridade e lustre à nobreza, podendo constituir um meio legítimo de mudança de estado, desde que não fosse resultante de processos ilegítimos de aquisição de bens. Por si mesma a riqueza não legitimaria tal mudança, carecendo, pelo contrário, de legitimação. $\bigcirc$ conceito central nesse processo seria o de honestidade. No caso da riqueza, haveria uma distinção fundamental entre a de ordens, os seus membros repartem-se por categorias hierarquizadas estanques, definidas segundo critérios ideológicos miticamente protegidos, às quais se tem acesso por nascimento ou por rituais de sagração. Neste tipo de sociedade fraturado do ponto de vista funcional, cada uma das suas partes constituintes tem uma função específica. Esse modelo sublinha a diversidade e irredutibilidade das diversas funções e, logo, também uma não intermutabilidade das suas partes" (DURÃES, 2013, p. 320).

17. Ibid., p. 341.

18. Durães, op. cit. e Pedreira (1995).

19. Miranda e Feitler (2016, p. 18).

20. Cf. Sucena (2007).

21. Hespanha (2006, p. 122, 123). 
22. Ibid.

23. Ibid., p. 125.

24. Os manuais de civilidade compunham uma abundante literatura produzida ao longo da Modernidade por toda a Europa Ocidental, que decodificava padrões idealizados de comportamento com o objetivo de ensiná-los e difundi-los. Inicialmente, tal difusão se limitava a segmentos sociais específicos que empregavam as civilidades como elemento de distinção. Posteriormente, no século XIX, ao serem utilizados no ensino, alcançaram um nível de difusão que não permitia mais tal uso (REVEL, 1991). As leis pragmáticas, lançadas com frequência durante o século XVII pelos monarcas portugueses, visavam controlar o consumo de artigos de luxo, proibindo a aquisição e o uso de peças de vestuário, móveis e ornamentos nos interiores domésticos e meios de transporte, bem como os gastos com o luto. Tais dispositivos legais restringiam o luxo aos setores mais ao alto na hierarquia social (CALANCA, 2008; SILVA, 2019).

25. Hespanha, op. cit., p. $125,128$. honesta e a desonesta. A primeira seria sobretudo a riqueza antiga, ao passo que a segunda seria obtida rapidamente, o que denotaria ambição ilegítima ou conduta desonesta. A ideia de mudança social na sociedade moderna apresentava limitações. Entretanto, estas não impediram a existência paralela de uma nobreza de nascimento e de uma nobreza política, que se adquiria por meio da vontade de promoção, expressa nas obras adequadas ov eficazes para a mudança de estado, concedida pela mercê do rei. Tratava-se do exercício de funções e/ ou ofícios da república. ${ }^{22}$

O honesto estaria intimamente ligado à honra, à hierarquia natural das coisas e às reações que essa hierarquia deveria suscitar: "a prestação das honras devidas é a atitude de quem mantém uma postura honesta". Essa atitude interior teria manifestações exteriores, como a conversação: "conversação honesta é a que traduz adequadamente, nos seus termos, nos seus temas e nas suas fórmulas, a relação justa (ajustada) entre os conversadores" ${ }^{23}$ A honestidade se aproximaria também da beleza, de maneira que no polo oposto à honestidade estavam o falso, o artificial, o desordenado ou o disforme.

Assim, o adjetivo honesto frequentemente acompanhava as referências ao traje numa ampla gama de textos portugueses produzidos na Modernidade, tais como os manuais de civilidade e as leis pragmáticas. ${ }^{24}$ Isso ocorria porque, nos quadros do pensamento daqueles que empregavam o termo, os vestidos representavam a qualidade da pessoa, incitando o respeito de seus observadores. Aqueles que fossem honestos deveriam se adaptar ao que os usos locais determinassem para cada grupo social.

A lógica da honestidade estava presente na questão dos trajes. E estes, nessa visão de mundo do Antigo Regime, vinculavam-se de maneira inextrincável às posições dos indivíduos no interior da hierarquia social vigente, bem como à fase da vida pela qual se passava, por exemplo a juventude ou a velhice, o luto e a viuvez. ${ }^{25}$ Era necessário garantir o respeito aos códigos de vestimenta, já que corresponderiam aos sujeitos como um todo, perfazendo uma ponte segura entre ser e parecer.

\section{OS TEXTOS DE CORDEL E A TENSÃO ENTRE SER E PARECER}

Os textos satíricos registrados nos folhetos de cordel constituíam um meio de ridicularizar e ironizar os vícios e os defeitos das instituições, costumes e ideias da época em que foram escritos. Os que foram produzidos no século XVIII português apresentam, entre os temas e assuntos de que tratavam, discussões sobre a tensão entre ser e parecer que se traduziam em ensinamentos acerca da 
necessidade de os sujeitos se portarem de acordo com seu lugar na sociedade. Esta, em tais textos, era concebida de acordo com o modelo tradicional tripartido em ordens. Para além das invectivas que proporcionavam o riso por meio da ridicularização dos usos da moda e das vestimentas, feitos nos diversos estratos sociais, um dos objetivos identificáveis em muitos desses folhetos estaria em sintonia com a manutenção de um modelo de sociedade incompatível com os processos de mobilidade social que se multiplicavam no período.

De acordo com Carlos Nogueira, literatura de cordel é uma designação que abarca um amplo conjunto de objetos impressos que, para serem expostos e vendidos, eram pendurados "em cordéis distendidos entre dois suportes, presos por alfinetes, pregos ou molas de roupa, em bancas e paredes de madeira, podendo também pender dos braços ou da cintura de vendedores ambulantes". ${ }^{26}$ Três marcas principais caracterizavam esses folhetos. Primeiramente, tratava-se de um espaço textual buscado por aqueles que compreendiam o conceito de povo enquanto grupo subalterno no sistema de distribuição social das oportunidades de acesso à cultura, à riqueza material e às decisões efetivas. Além disso, nesses textos havia uma conexão entre oralidade e escrita, proveniente dos padrões médios de letramento de seus consumidores, o que permitia alcançar um vasto público, incluindo aquele caracterizado pelo analfabetismo funcional. Por fim, esses impressos eram escoados a baixos preços num extenso circuito de vendas.

Os textos de cordel, assim, levavam as ideias de um autor a um amplo público. Esse material se torna uma fonte muito inspiradora e útil para conhecer aspectos de algumas dinâmicas envolvendo as aparências no meio social, bem como alguns elementos da cultura material nelas empregados. Temas variados eram tratados de maneira satírica. A dissimulação de uma condição social superior por meio do trato de si, a hierarquização dos sujeitos na sociedade portuguesa do século XVIII, a valorização de itens da moda e a afetação de homens e mulheres nos modos de se apresentar socialmente são alguns deles. As críticas ácidas direcionadas a elementos diversificados, como a maneira de andar, as posturas, os gestos, entre outros, compõem reflexões sobre os códigos corporais da época e são preciosos indícios do valor social dos gestos. ${ }^{27}$ Assim, além de dar a conhecer os artefatos empregados nos cuidados da aparência, estes textos os contextualizam, sublinhando, por vezes, sua relação com o corpo na composição de uma imagem a ser apresentada perante a sociedade em ocasiões diversas.

De acordo com Maria José Moutinho dos Santos, na segunda metade do século XVIII houve uma grande difusão dos folhetos de cordel, que eram impressos em papel de baixa qualidade e com tintagem ruim. Apresentados em caderninhos em quarta, em sua maioria com dezesseis páginas, por vezes portavam textos 
28. Santos, (1989, p. 137164).

29. Costa (2007). reimpressos ou traduzidos. Foram extremamente populares e de grande sucesso editorial. Seu público se situava em diversos níveis da escala sociocultural. Por meio da prática da leitura em voz alta, esses textos se difundiam até mesmo entre as camadas populares analfabetas, principalmente nos ambientes urbanos, corroborando a ideia de uma ampla difusão dos assuntos apresentados. ${ }^{28}$

Quando devotados ao assunto da moda e das aparências, esses textos trazem representações de situações e de tipos sociais, por intermédio dos quais se colocava em evidência uma série de comportamentos sociais condenáveis ou apreciáveis, na perspectiva de seus autores. Trata-se de críticas realizadas por meio da sátira que questionavam os usos da moda e da aparência como instrumentos para ascender no meio social. Os textos satíricos em apreciação colocavam em jogo, de maneira velada, modelos ideais contrapostos às caricaturas estereotipadas.

Nesse sentido, a obra de Frei Lucas de Santa Catarina tem grandes contribuições para este estudo. Em Anatômico jocoso foram reunidos textos que circularam em manuscritos, com numerosas cópias, na primeira metade do século XVIII, das quais ainda restam algumas na Biblioteca de Coimbra, na Biblioteca Nacional, na Biblioteca da Ajuda e na Biblioteca de Évora. Frei Lucas nasceu em Lisboa, em 1660, e morreu oitenta anos mais tarde na mesma cidade. Em 1680 professou na Ordem dos Pregadores, situada no Real Convento de Benfica, e se tornou cronista de sua província. Foi, também, um membro fundador da Academia Real da História Portuguesa, onde produziu amplamente matéria jocosa, bem como religiosa. De acordo com Ana Cecília Machado da Costa, nem todos os textos do Anatômico jocoso seriam de Frei lucas, que teria assumido diferentes pseudônimos, pois era um religioso escrevendo obras profanas. ${ }^{29}$ Seus textos apresentam variados exemplos de como a moda e sua relação com uma aparência distintiva eram percebidas na sociedade. Sua pena registrou ácidas críticas abertas e veladas ao fenômeno da mudança e aos seus seguidores, em relação com as dinâmicas da imitação e suas decorrências em meio aos diversos grupos sociais, despontando na criação de tipos sociais ou caricaturas estereotipadas cujo fundamento era satirizar comportamentos condenáveis aos olhos do autor.

Para esta pesquisa foram selecionados textos de cordel reunidos no Anatômico jocoso. As análises se fundamentam na leitura de todo o primeiro volume da obra, composto por textos que originalmente foram impressos e divulgados separadamente. Nos volumes seguintes estão reunidos entremezes e cartas. $\bigcirc$ volume em questão é composto por 24 textos, dentre os quais oito, ou seja, um terço, retratam aspectos do estereótipo do faceira ou semelhantes. Os excertos usados como exemplos foram transcritos de quatro textos que constam da bibliografia deste artigo, nos quais se destacaram de maneira mais enfática, 
por meio da sátira, as temáticas da aparência e da estrutura social, dando a perceber pressupostos adjacentes à obra. ${ }^{30}$

\section{A CRITICA DAS APARÊNCIAS NA OBRA DE FREI LUCAS DE SANTA CATARINA}

Em Turina cotidiana, Frei Lucas de Santa Catarina descreveu as rotinas de cuidados com a aparência, apresentando uma miríade de artefatos nelas empregados. $\bigcirc$ autor se devotou, nesse texto, a satirizar os homens excessivamente vaidosos por meio do faceira, caricatura estereotipada formulada para enfatizar a futilidade - suas preocupações giravam apenas em torno de sua aparência e do momento de sua exibição:

Em Deus amanhecendo, se levantará o verdadeiro Faceira, e sairá a janela, a ver como está o tempo, desejando entranhavelmente que se não estirem os cabelos, e se the não sujem os sapatos, e o vestido; [...]

Sairá para fora bamboleado de corpo, e aflamengado de gesto, entre arremessado, e direito, já se entende que com braços de arame [...]. Assim preparado, caminhará o nosso Faceira para a lgreja, onde houver Festa, e na falta dela recorrerá em todo o caso ao Lausperene, que neste particular é alivio de tristes, e consolação de queixosos.

Entrará na lgreja arrastando o sapato, e rapando com toda a sola, que faz o passeio mais airoso $[\ldots] .^{31}$

Frei Lucas destacou o ritual matinal dominical do faceira. Logo que se levantava, avistava as condições do tempo, desejando que não atrapalhassem a manutenção de seu penteado e a limpeza de seus sapatos e roupas. $\bigcirc$ faceira se lavava em frente ao espelho. Já vestido, tirava o toucador e preparava os cabelos para o dia. Acertando os detalhes dos acessórios da vestimenta, pegava o chapéu para sair à rua. Seu jeito de andar foi caracterizado para provocar o riso: a descrição apresentava movimentos acentuados - bamboleado de corpo, entre arremessado e direito, com braços de arame, ou seja, endurecidos - que, ao contrário da intenção de elegância, o tornavam ridículo aos olhos do narrador e daqueles que compartilhavam de sua maneira de perceber a aparência e a gestualidade alheias. A forma como o faceira arrastava os sapatos também era contrária à intenção de elegância. A passagem, apesar de rápida, evidenciava um elemento profundo da construção do estereótipo em escrutínio: aos olhos do
30. Como forma de aprofundar a compreensão deste material, foram lidos textos de cordel de outros autores posteriores que apresentassem elementos para a análise das relações entre aparência, artefatos e hierarquias sociais. Esses textos, entretanto, não serão trabalhados neste artigo.

31. TURINA COTIDIANA, $v$. 1, p. 1-2. 
32. Id., v. 1, p. 8-9.

33. Id., v. 1, p. 6, 8-9.

34. Id., v. 1, p. 21. Barrela era a cinza que se fervia na água, com que se lavava a roupa (BLUTEAU, 17121728 , v. 2 , p. 55$)$. autor, o personagem parecia não conhecer o uso correto dos artefatos indumentários, exagerando nos gestos que enfatizavam a posse de alguns deles.

A rotina descrita por Frei Lucas para os outros dias da semana fixava seus pontos principais na preocupação do personagem em se exibir. Paralelamente, a caracterização do faceira se aprofundava, revelando seu pertencimento a estratos inferiores da sociedade. Assim se confirmava a falsidade de sua aparência, que pela artificialidade redundava em ridícula. Em seu desejo de nobreza, o faceira não trabalhava. Seus dias permaneciam vazios de atividades produtivas. Às segundas-feiras, por exemplo:

este dia é comumente desocupado; se não houver festa votiva, passa-se a sua manhã em casa, de bonete, e roupa de chambre [...]. De tarde, bem trabalhado de vestido, e de cabelo, sairá o nosso Faceira a dar uma volta ao seu bairro, namorando de bofarinheiro, apregoando, com muda ostentação, os punhos, a gravata, a fita, e o mínimo trapinho com que se achar na sua limpeza. ${ }^{32}$

Seu vestuário, apesar de descrito de maneira a caracterizar pobreza, combinava-se aos espaços e momentos, mostrando variedade de peças, sugerindo grande investimento na aparência e na adequação dos trajes às situações, algo que, possivelmente, nas considerações do autor, não lhe seria pertinente. $O$ faceira era uma representação caracterizada como alguém que mal tinha o que comer, mas cujas preocupações se centravam em parecer: "assim passará a manhã a seco, e o jantar em claro; porque o verdadeiro faceira há de comer de sucesso, e não de propósito, desjejuando-se venturosamente em casa de uma amigo, que não ande no mesmo fadário". ${ }^{33}$ Essa busca por alimento em casa alheia reforça a construção de uma imagem parasitária do personagem.

Aos sábados, após ir à igreja, o faceira realizava os cuidados necessários com as roupas:

Já em casa se porá em fresco, dando uma barrela ao mínimo trapinho da sua gala; ao cabelo dar-the-á mais um garrote, para que the fique melhor a carga dos polvilhos; à gravata, e punhos, dar-thes-á o seu sabão; ao sapatos, zuzir-hhes-á o couro com umas mãos de unto; e ainda que tenham uma abertura por baixo, e façam água, tudo dissimula uma crena de sebo: ao chapéu dar-the-á com uns pós, e ainda que já não esteja para isso, tornará a servir $[\ldots]^{34}$

Todas as peças de roupa que constituíam o traje de rua, ou seja, a gala, eram lavadas. A limpeza das roupas figurava como um elemento de distinção no 
período e o fato de o faceira lavá-las corroborava sua intenção de parecer melhor do que realmente seria. ${ }^{35}$ Entretanto, ele mesmo realizar todos os cuidados para com suas roupas, estando em casa, sugere que as quantidades fossem reduzidas, o que o obrigava a usar sempre o mesmo traje, reforçando a ideia de se tratar de alguém sem cabedais. Seus sapatos eram untados e esfregados, mantendo a boa aparência mesmo que furados nas solas. Os chapéus recebiam pós com a mesma finalidade. Os artifícios para fazer os sapatos e o chapéu parecerem novos integram a narrativa como meio de reafirmar a ausência de posses e a dissimulação do personagem. Tratara-se de artefatos corrompidos pelo tempo e pelo uso, mas que, com a aplicação de sebos e pós, tinham sua aparência falsificada, coadunando sua artificialidade.

A sátira do religioso se servia de um estereótipo masculino presente em muitos outros escritos da época: peralta, bandalho, bandarra, bonifrate, faceiro, frança, francelho, franchinote, peralvilho, petimettre, sécia, taful e xibantão foram designações usadas ao longo do século XVIII para caracterizar "o par dos elegantes ridículos e parasitas que se exibiam na sociedade de Setecentos", conforme assinala Marta Pinha Norton. Cada um dos termos traduzia um mesmo conjunto de características gerais, calcado no apreço excessivo pela aparência e pelas vestimentas, variando alguns traços morais: o xibantão, por exemplo, era matizado pela demasiada imponência e orgulho; o faceira, caracterizado como nobre inculto de trejeitos afrancesados, por sua vez, era marcado pelo vazio e futilidade; iá o peralta era a figura do vaidoso miserável. ${ }^{36}$

As críticas realizadas por meio da sátira de Frei Lucas encontravam paralelos e semelhanças nos escritos de outros autores, veiculados por meio dos follhetos de cordel. As questões sociais e o preconceito em relação à mobilidade social dos sujeitos marcaram de maneira profunda esses textos, cujo objetivo principal se relacionava a ensinar a cada um seu devido lugar na sociedade, por intermédio de situações e personagens risíveis. Ao ler ou ouvir a leitura desses textos, sujeitos de todos os estratos sociais poderiam passar a identificar, segundo as características usadas na construção dos personagens, homens e mulheres que se aproximassem dessas composições em seus usos e gestos. Assim, os textos de cordel, fundamentados em visões preconceituosas, forneciam elementos-chave que poderiam servir de critério para julgar as aparências alheias. Esse julgamento, por sua vez, buscava estabelecer certa estabilidade na tensa relação entre ser e parecer, condenando usos e gestos considerados impertinentes aos integrantes dos estratos mais baixos da hierarquia social portuguesa do período.

As imagens construídas pela pena de Frei Lucas eram exageradas e fruto de uma visão de mundo conservadora, segundo a qual ser deveria corresponder a parecer. Do descompasso entre ser e parecer nascia toda a artificialidade atribuída ao faceira: por não nascer nobre, sua dissimulação enfaticamente se afastava do 
37. Fiadeiro (2007, p. 168).

38. ELOGIO..., v. 1, p. $42-43$. natural, seus gestos eram exagerados, suas falas e conversações não tinham fundamentos reais, sua vestimenta camuflava sinais de velhice e corrupção por meio da limpeza. Nesse sentido, esses textos defendiam que a indumentária deveria estar alinhada à condição social do sujeito, sendo os tecidos os ornamentos de luxo reservados aos nobres. Simultaneamente, esses escritos condenavam o desejo de ascensão social e as melhorias do trato de si como estratégia para alcançar respeito e admiração na sociedade. A materialidade dos vestidos deveria compor uma imagem condizente com cada estado, corroborando as hierarquias correspondentes a um modelo conservador de estrutura social.

Paula Cristina Neves Fiadeiro, ao estudar $\bigcirc$ cortesão, de Baldassare Castiglione, analisou as argumentações em torno da questão da constituição de um perfeito cortesão. Segundo a autora, existia um pensamento segundo o qual a procedência aristocrática conferia aos sujeitos um dom natural que se manifestava numa consciência estimuladora da virtude proveniente da própria ascendência, cujos méritos eram capitalizados a favor de sua reputação. Dessa maneira, tais dons quase dispensavam os cuidados da boa criação e o estudo, ainda que fossem importantes na constituição de um perfeito cortesão. Agradar e auferir boa reputação seria "cair nas boas graças dos outros", o que implicava, em larga medida, fugir a todo tipo de excesso ou, usando a terminologia da época, afetação. Ao cortesão, caberia "se esforçar para parecer natural, esforçando-se para disfarçar esse esforço, sem que seja notado". Segundo esse raciocínio haveria uma tensão entre ser e parecer, entre realidade e artifício. A habilidade, ou arte, deveria ser imperceptível, pois deixar transparecer o referido esforço colocaria em causa a verdade do conteúdo. Qualquer desequilibrio entre ser e parecer transformava a representação em um fim em si mesmo, - que era considerado uma degeneração, constituindo um tema amplamente aproveitado pelos pensadores e moralistas para afrontarem os excessos de ornamentos sem substância. ${ }^{37} \mathrm{Na}$ Turina cotidiana, a ideia de que a boa desenvoltura estava naturalmente atrelada à nobreza dos sujeitos se fazia presente de maneira implícita.

Os faceiras e outros estereótipos estavam apartados da fidalguia e isso implicava a maneira como usavam seus artefatos indumentários:

[...] que havia de fazer nesta Cidade um miserável Bandarra, senão trazer as fivelas dos sapatos metidas para dentro; porque a força dos joanetes ocasiona estas desigualdades? Ligas nas pernas para maior inchação das barrigas, capa de crescer, calções a mamar, porque junto as tetas: com dois pires de prata por botões, e a prata do boldrié, vem a fazer uma copa de batizar, ou uma mula de coche com arreios. [...] Se traz cabeleira, o topete sempre anda metido nos olhos, e o rosto embutido em cabelos [...] a fita do chapéu muito estirada pela copa, para que the conheçam a largura da fita. ${ }^{38}$ 
A maneira como o uso das peças de vestimenta e acessórios foi descrita no excerto sugere se tratar do registro de uma forma de percepção da aparência alheia. Tais percepções tinham limites e enquadramentos decorrentes da posição social dos sujeitos e de suas condições materiais de vida: o que seria representativo de elegância para os vilões estaria em desacordo com o padrão de elegância acreditados nos altos escalões da sociedade. ${ }^{39}$ Nesses padrões vigentes nos olhares provenientes do alto da sociedade eram considerados os mínimos detalhes do caimento dos trajes. A maneira de trajar se tornava elemento diferenciador: o direcionamento das fivelas dos sapatos, em virtude da existência de joanetes, a altura dos calções no tronco dos indivíduos, as cabeleiras que não se adequavam aos rostos, caindo-thes nos olhos, ou a fita do chapéu, estirada em demasia para ostentar sua largura e consequente valor monetário, eram elementos que desqualificavam a aparência dos vilões. Eles portavam os artefatos indumentários apregoados pela moda, mas não sabiam fazer uso deles, demonstrando ignorância nas sutilezas da aparência e do bom gosto. ${ }^{40}$

Os homens não foram os únicos cujo comportamento a satírica pena de Frei Lucas desejou regrar, ou ao menos, ridicularizar. As mulheres também foram retratadas em seus escritos. Seus textos deixam transparecer que, no pensamento do autor, independentemente de seu estado de nascimento, elas pecavam em favor da vaidade da aparência e das modas. A Turina fêmea era, portanto, direcionada ao público feminino no geral, que, segundo o autor, cometia excessos maiores do que o masculino:

É lastima verdadeiramente conhecida, que saindo uma Turina para o aproveitamento de todos os Faceiras, não houvesse até aqui quem quisesse publicar outra para o estado Feminino, aonde com maiores excessos se vê a Bandarrice, a moda se conhece, e se encrespa a bizarria, fazendo-se geral em toda a casta de Dama, Senhora, e Cozinheira! [...] E pelo lastimoso estado em que está este século, não haverá diferença de pessoa no traje da moda, porque é universal a bandarrice. ${ }^{41}$

Os usos e abusos no trajar eram graves e difundidas infrações aos olhos do autor, tanto que comprometiam o diferenciar das pessoas por meio de sua identificação em relação ao pertencimento a determinado estado, identificação feita por meio das roupas, acessórios indumentários, matérias-primas que lhes constituíam e estado de conservação. As características materiais pesavam no julgar das aparências alheias tanto quanto o modelo das roupas ou a maneira de empregar tais elementos materiais sobre o corpo. $\bigcirc$ autor divide a Turina em três advertências: a primeira de "Senhora", mulher de contratador para baixo; a
39. De acordo com Pierre Bourdieu, "num universo em que tudo é classificado, portanto, classificante [...] um domínio perfeito das classificações (que os árbitros da elegância se apressam em considerar démodé assim que se tornam muito comuns) é indispensável para obter o melhor rendimento dos investimentos sociais e para evitar ao menos ser identificado com grupos menos cotados. [...] porque nada varia tão claramente segundo a posição de alguém na classificação do que sua visão da classificação" (BOURDIEU, 2013, p. 110).

40. Os usos feitos dos bens e objetos, mais do que sua posse, funcionam como marcas de distinção. O uso é o que permite, no jogo da divulgação e da distinção, a percepção da excelência humana, "aquilo que toda sociedade reconhece no homem cultivado" (BOURDIEU, 2009, p. 16).

41. TURINA FÊMEA..., v. 1, p. $67-89$, p. 71 . 
42. Id., v. 1, p. 72.

43. Id., v. 1, p. $72-73$.

44. Daniel Roche assinala a importância dos criados para a difusão das modas na Paris do século XVIII: para além das librés, os criados mais ricos imitavam o comportamento de seus senhores no que dizia respeito às vestimentas, com investimentos significativos em roupas, o que resultava na posse de mais peças de roupa do que os pobres em geral. Roupas velhas e usadas integravam a remuneração, juntamente com comida e alojamento, e muitas peças eram legadas aos criados por meio dos testamentos de seus senhores. De acordo com o autor, "por mimetismo ou osmose, os criados eram agentes de uma profunda transformação social e cultural. A socialização indumentaria era ao mesmo tempo signo e consequência desse papel, que provavelmente remonta aos primórdios da era moderna. Além disso, esse papel afetava a todo o corpo social, uma vez que os criados punham em contato o campo e a cidade, meios refinados e inferiores" (ROCHE, 2007, p. 113).

45. A sociedade de corte fez prevalecer e valorizou os cuidados com a aparência, pondo em voga o uso de produtos de maquiagem, artifícios de moda e penteados. Esse processo teria levado a uma estética feminina fabricada. De acordo com Berta Sucena, "a luta contra a fealdade e o envelhecimento, com recurso à arte de disfarçar e iludir (mediante cosméticos, artifícios, e postiços que possibilitavam uma 'metamorfose estética'), servindo pretensões pessoais funcionava também como valorização social" (SUCENA, 2007, p. 21). segunda para "Damas" e a terceira para "Cozinheiras". Seu objetivo era possibilitar que todas observassem as "Leis da verdadeira Turina, e bandarrice moda, e os mais airosos donaires do alinho, e verdadeiras palatinas dos adornos". ${ }^{42}$ Entretanto, ele se prolonga muito mais nos comportamentos das senhoras, a quem direcionou a primeira advertência, o que pode ser indicativo de seu verdadeiro alvo. As advertências dirigidas às damas se restringem a uma página e meia e retratam uma dama já jubilada em Mafra. As advertências às cozinheiras se circunscrevem a cinco páginas. As advertências às senhoras, por sua vez, ocupam dez páginas que serão analisadas a seguir.

A advertência às senhoras apresenta a caracterização de certa futilidade, que parece proporcional ao poder aquisitivo na narrativa. Essa foi a categoria de mulheres com a qual o autor teve maior preocupação ao definir traços de uma espécie de vítima da moda.

A verdadeira Senhora, para ser legitimamente graduada na regra da bandarrice, há de ter infalível notícia das modas Inglesas, Alemãs, Francesas, e Holandesas, para que saiba votar na Irmandade dos Toucados, e na Confraria dos Topetes, e juntamente ter eleição no Congresso das Cores, para que assim se aprove de bom gosto. E para que the seja menos custoso o saber destes enlaçados enfeites, terá uma amiga no Paço para a informar de todas as modas; pois é a base donde sai todo o gênero de invenção da moda legitima. ${ }^{43}$

A moda legítima nasceria na corte, inspirada em modelos internacionais diversos, e era difundida em outros locais por meio de pessoas que transitassem por esse espaço, como trabalhadores e criados, por exemplo. ${ }^{44} \mathrm{~A}$ informação sobre as modas era fundamental para que as escolhas das vestimentas e adornos resultasse em uma aparência que afirmasse o bom gosto. Além disso, o autor zomba da importância desse fenômeno ao afirmar que "toda a notícia, que der esta amiga, há de observar-se sem controvérsia alguma". Isso seria o mesmo que admitir e usar tudo o que fosse apregoado pela moda, sem filtrar ou escolher.

○ toucador seria como uma caixa de ferramentas da dissimulação da aparência feminina, pois, além dos toucados, penteados e cores, a boa aparência dependia de outros elementos, como os cosméticos. ${ }^{45}$ Vidros de água de rosto, vidrinhos com óleo de jasmim, tigelinhas com brandura, cor, pomadas de várias castas e sinais compunham o conjunto de artifícios por meio dos quais as senhoras angariavam esconder sinais da idade e imperfeições da pele, bem como a ornamentação dela. Os pentes eram variados e serviam a funções diferenciadas: "um de riçar o topete, outro de desempeçar o cabelo, e outro de tirar alguma". O ritual de beleza de todas as manhãs tornava necessário vestimenta e acessórios adequados: "um penteador de 
rendas, duas toalhinhas para limpar, mais dois paninhos com que se assenta a cor, e se limpam os dedos, que ficam untados com as enxundias do rosto". Uma escovinha era necessária para limpar os pentes, bem como uma caixa redonda, coberta com tafetá, para guardar os pós. A descrição da materialidade do toucador remete ao parecer mais do que era: "Terá esta senhora o seu toucador do melhor modo que puder ser, e quando não o possa ter com todos os erres (que é palavra também moda), basta ter uma banquinha com seu espelhinho de espeque[...]". ${ }^{46} \bigcirc$ estereótipo da senhora construído pelo autor fingia duplamente: escondia defeitos estéticos por meio da maquiagem e ostentava uma condição social à qual não pertencia.

O detalhamento do que se usava para melhorar a aparência feminina pela manhã sugeria o tamanho do embuste empregado pelas senhoras. Os artifícios femininos, como a maquiagem e os sinais, configuravam um núcleo distinto no interior da temática da dissimulação social. Eles constituíam meios que corroboravam a falta de correspondência entre ser e parecer, expressada, sobretudo, na aquisição de beleza e na correção de defeitos. Conforme mostrou Georges Vigarello ao fazer uma história da beleza a partir do caso francês, a maquiagem foi, ao longo do século XVII, ora permitida, em determinados contextos e idades, ora condenada, associada à vaidade e à desobediência feminina, especialmente no pensamento religioso. Ao longo do século XVIII, entretanto, um deslocamento afetou a desconfiança moral que pairava sobre o artifício: não se tratava apenas de enganar a Deus, mas, também, de mentir para os outros. A maquiagem passava, assim, a ser vista como um obstáculo à transparência social. ${ }^{47}$

Na rotina das senhoras, conforme elaborado na Turina fêmea, havia uma separação entre a roupa que se vestia para ir à rua, se expor no espaço público, e aquela que se usava longe dos olhares, para estar em casa, em companhia das criadas.

Levantar-se-á a Senhora da cama e vestirá umas roupinhas, (que parecem de lavapeixe) meterá umas chinelas nos pés, de couro encarnado, com seu galão de prata; um guardapé de primavera já usado; e com o cabelo todo emaranhado, virá logo para o Toucador. Terá duas criadas, uma do trato da cozinha, e exercício da vassoura; e outra com vezes de aia. ${ }^{48}$

Vestuário de casa era mais simples, com menos peças sobrepostas e mais velhas - daí que o autor afirme parecerem com lavapeixe, ou seja, a mulher lou homem) que tinha por ofício lavar os peixes depois de descamados. ${ }^{49} \bigcirc$ galão de prata nas chinelas contrastava com o vestido descrito na narrativa, sublinhando a incoerência da aparência da senhora que, em casa, assim como o faceira da Turina cotidiana, deixava transparecer certos aspectos de sua verdadeira imagem. A senhora
46. TURINA Fêmea..., v. 1, p. 73. Espeque: "pau com que se esteia, ou escora alguma coisa, para não cair” (SILVA, 1813, v. 1, p. 758).

47. Vigarello (2006).

48. TURINA FÊMEA..., v. 1, p. 74-75

49. Bluteau, op. cit., v. 5, p. 52; Silva, op. cit., v. 2, p. 209. 
50. Cf. Lopes (1989).

51. Ibid.

52. A Saia de bambolins era uma saia adornada com folhos, ou seja, guarnecida pela borda com um pano mais fino (SILVA, 1813, v. 1, p. 257). Palatina: peça de adorno feminina, feita de pele ou penas, que rodeava o pescoço e descia para ser cruzado no peito, tendo pouca largura e sendo usado no frio (SILVA, 1813, v. 2, p. 385). Rosicler: joia de cabeça das mulheres, com formato quase piramidal, com pingentes trêmulos de várias castas (BLUTEAU, 1712-1728, v. 7, p. 380).

53. De acordo com Marta Norton, "tal como a aparência, o tratamento funciona como primeiro elemento de impacto que deve impressionar". Disso resultava uma espécie de febre entre os elegantes pelo tratamento "Dom", que era proibido pelas pragmáticas dos tratamentos, lançadas em $1597 \mathrm{e}$ 1739, que estabeleciam penalidades para quem exigisse o tratamento sem dele ter direito, bem como para aqueles que davam o tratamento indevidamente (NORTON, 2000, p. 47).

54. TURINA FÊMEA..., v. 1, p. 78 .

55. Id., v. 1, p. 79. era servida por duas criadas apenas, o que denotava a limitação de sua riqueza, ao mesmo tempo que garantia sua isenção dos trabalhos da casa. Conforme o texto, sua criada, que fazia vezes de aia, costurava, bordava, entendia de tecidos, de adornos e de seu uso no processo de confecção, bem como sabia pentear e maquiar como no Paço. A exibição de criados bem-vestidos e com numerosas habilidades integrava os mecanismos de ostentação de uma posição social elevada. ${ }^{50}$ Ao descrever o penteado escolhido pela senhora para estar em casa, o autor insinua sua simplicidade ("não fará mais que..."). Entretanto, arremata a descrição afirmando satiricamente se parecer com um "resplendor de Santo de Aldeia". A seleção dos elementos que compunham a aparência, como penteados, roupas e adornos, conforme sublinhou Maria Antónia Lopes, demonstra as escolhas de como ser e estar reivindicadas pelas mulheres retratadas na sátira. Justamente por isso os autores de folhetos volantes se empenhavam em criticar tais elementos, geralmente identificados com as novidades da moda. ${ }^{51}$

Como sugere a Turina fêmea, a exposição em ambiente público levava as senhoras a capricharem no trajar. Indo a pé a alguma festa pela tarde, se acompanhavam das criadas e faziam uso de todo ornato: manto de lustro, saia de bambolins, guarda-pé adornado de galão estreito, colete à inglesa com palatina e muitas joias ${ }^{52}$ - broche no peito, pérolas no pescoço, em cordão negro, cruz de diamantes e esmeraldas, um rosicler irmão da cruz no topete, luvas de pala e alguns anéis de boas pedras. $O$ comportamento deveria ser severo, tanto no andar como na conversação, que deveria ser facilitada somente com pessoas de sua qualidade, por sua vez, tratadas por "Dom". ${ }^{53}$

Ao descrever o comportamento da senhora bandarra na igreja, o autor a assemelha em diversos pontos ao faceira: "e eleve-se tanto nessa conversação, que The não lembre outra coisa, nem reze, nem faça caso da Missa; que todas as vezes que tiver o sentido nas modas, e nas guapices, isso lhe basta para a salvação da sua alma Turina". A igreja seria o local da exibição da senhora, para onde se dirigia sem interesses religiosos: "e quando ouvir a Missa não se the dê de estar assentada a maior parte do tempo; que assim inculca Fidalguia, e ser um tanto achacada de flatos". ${ }^{54}$ Ao sair da igreja, os ventos configuravam mais uma oportunidade de ostentar o luxo de seu vestuário:

e se acaso fizer algum vento, com melindre de Senhora, chamará pela criada, que se chegue a ela para lhe não verem os pés; mas não tão chegada que se the não vejam os sapatos, que serão feitos de veludo berne, agaloados com passamanes de ouro, feitos pela tal criada: e ainda que veja muita gente no adro, não faça caso de nada e vá passando com a cara severa, e aspecto senhoril. .5 
As posturas e os gestos da senhora, assim como do faceira, ajudam a compor a artificialidade do personagem. Ficar em pé durante a maior parte da missa, para demonstrar nobreza; pedir que a criada se aproxime para evitar que os ventos façam seus pés aparecerem, mantendo o pudor, mas sem esconder os sapatos; manter um aspecto severo no rosto e passar pelas pessoas sem thes prestar reverência ou cumprimentar, são elementos que, adotados no comportamento público, auxiliariam tais personagens a parecerem ocupar posições sociais mais elevadas. Todavia, como não eram comportamentos considerados pertinentes ao seu real estado, convertiam-se em dissimulação e provocavam o riso. Ademais, possivelmente, as descrições desses comportamentos satirizados criavam uma espécie de índice para identificar, nos comportamentos alheios observados nos espaços públicos cotidianamente, posturas e gestos risíveis, portanto condenáveis.

A Turina fêmea, proposta como uma versão da Turina cotidiana devotada aos comportamentos femininos referentes à aparência, não se distanciou do texto que the serviu de modelo. Ao compor as advertências às mulheres de três estados diferentes, a dama idosa, a jovem senhora e a cozinheira, o autor optou por não as descrever por meio de figuras como o faceira, mas criou outros estereótipos. A sátira e os elementos risíveis foram construídos com base na aparência dissimulada das mulheres, tanto no que se referia à ostentação de uma posição social superior e impertinente quanto na ocultação de defeitos estéticos. A isso o autor adiciona os conflitos entre homens e mulheres, gerados pela autonomia que estas expressavam nas escolhas das vestimentas. No texto em escrutínio, a aparência não se alinhava com o ser, pois os tipos sociais em questão desejavam parecer melhores do que realmente eram, segundo a compreensão do autor.

A mobilidade dos sujeitos pelos diversos degraus sociais compunha uma matéria de grande importância no conjunto de textos em análise. As críticas direcionadas às possibilidades de ascensão social tomam contornos bem definidos no Discurso sobre as palavras do serolico berolico, quem te deu tamanho bico? 56

Sabeis o que é Serolico? É todo o gênero humano; é todo o indivíduo do tempo, e com ele aumentado [...]

Serolico, é o Bandarreta, até agora com sua casaquinha velha, sobre curta; sua peruca de bolsa já posta no engaço do cabelo, do joelho para baixo posto no calçado velho: agora já todo peruca Inglesa; todo luva branca; todo galão de prata, boneco de cupido; títere de Vênus; [...]. Serolico, quem te deu tamanho bico? 57

56. DISCURSO..., v. 1, p 131-144.

57. Id., v. 1, p. 132 
58. Id., v. 1, p. 135-136. Têmporas eram quatro jejuns de preceito da Igreja nas quatro estações do ano, em três dias de uma mesma semana (quarta, sexta e sábado) (BLUTEAU, 17121728 , v. 8 , p. 90 ). Mealheiro seria um recipiente onde se colocavam as esmolas em alguns tribunais em que se distribuía dinheiro (BLUTEAU, 1712-1728, v. 5, p. 377). No texto, a expressão "mealheiro humano" se refere ao fato de o personagem viver de esmolas. Cabidela era um prato feito com pedaços de aves e seus miúdos (BLUTEAU, 17121728 , v. 2 , p. 12 ). serolico, conforme aponta o autor, seriam os "indivíduos do tempo, e com ele aumentados". A vaga definição indica o aumento dos indivíduos com o passar do tempo. Para compreender a natureza do referido aumento é necessário observar cada um dos muitos exemplos que o autor fornece ao longo do texto. A começar pelo Bandarreta mencionado no excerto anterior, cuja caracterização inicial, pautada nas roupas velhas, salta para uma aparência renovada e muito conforme as modas da época. Acompanhando tal aparência, o autor aplica ao personagem uma série de qualificativos que o inserem, para além da designação inicial (Bandarreta), no universo dos faceiras. A questão, repetida ao final de cada parágrafo é colocada como meio de imputar desconfiança sobre a mudança das condições materiais descritas: "Serolico, quem te deu tamanho bico?" poderia ser uma questão colocada, em outros termos, para indagar sobre o que teria possibilitado tais transformações. $\bigcirc$ autor, evidentemente, imputava suspeita sobre os caminhos que teriam levados tais sujeitos a melhorarem sua aparência e sua apresentação. Veja-se mais um exemplo:

Serolico, é aquele ratinho observante, minhoto descalço, para o terreiro correndo com o sa$\mathrm{co}$, para o açougue com a gamela, para o chafariz com a quarta, de encamisada em janeiro, de Têmporas todo o ano, vazando a barriga na bolsa, pagando o estomago de vazio, mealheiro humano, e dizimeiro de si mesmo: ei-lo já racional gafanhoto, ei-lo salta a caixeiro, ei-lo pula a negócio, ei-lo trepa a contrato, ei-lo se pranta de cabedal na praça, de cabidela na mesa, de gala na rua, e de regalo na sua quinta. Serolico, quem te deu tamanho bico? 58

No excerto, a ascensão social visível do personagem chocava o autor, que lançava dúvida sobre quais engrenagens teriam permitido as mudanças notadas. Tratava-se de um personagem que ascendeu por meio de atividades comerciais, caminho que se tornava comum em Portugal entre os processos que levavam em direção ao alto da sociedade na modernidade. Muitos tipos de serolicos foram apresentados no texto, todos dando margem à interpretação de que se trataria de exemplos comuns de mobilidade social, que, sob novas condições materiais, adquiriam comportamentos, vestuário e aparência geral mais refinados.

$\bigcirc$ aprimoramento ou refinamento das vestimentas era indicativo da ascensão social. No universo representado, os objetos corroboravam materialmente o estabelecimento de hierarquias. Os modelos das peças, o tecido e os adornos nelas empregados diferenciavam as vestimentas descritas no texto. Materiais como ouro e prata, em fios, bordados ou em botões, e tecidos de sedas, considerados nobres, eram os principais marcadores visuais a compor uma aparência mais digna, correspondente de um posicionamento mais alto na hierarquia social: 
Serolica de manto, é a que passa da sarja ao lamego. Serolica de saia, é a que passa ao crepe da estamenha. Serolica de toucador, é a que passa dos nastros aos cornichos. Serolica de orelha, é a que passa do azeviche a cabaça. Serolica de sapato, é a que passa do cordovão veterano ao marroquim garrido. Serolica de palmo, é a que passa da luva de pele ao couro. Serolica por dentro, é a que passa do colete a roupinha, do lenço ao capotinho. Serolica de pompa, é a que continua o solo de si mesma com o acompanhamento da criada. Serolica preciosa, é a que com o broche resgatou a testa da humilde prisão da fita. ${ }^{59}$

Ao trocar os tecidos de que eram feitas suas roupas (sarja para o lamego, estamenha para o crepe), os brincos de azeviche (pedra mineral preta leve e frágill) por cabaças (brincos compostos de duas pérolas, uma menor, posicionada acima, e outra maior, posicionada abaixo, que se assemelham ao fruto da cabaça), e o modelo de peças que perfaziam funções semelhantes no vestuário / o colete pela roupinha, o lenço pelo capotinho), bem como passar a ser acompanhada de criada no espaço público, as mulheres ganhavam maior dignidade no interior da escala social pelo trato melhorado de sua aparência, na qual empenhavam maiores investimentos.

Todos os casos de mudança social transmutados no texto em tipos de serolicos e serolicas pareciam repentinos e não fundamentados, conforme a descrição construída pelo autor. Processos repentinos, antinaturais e, portanto, desonestos. Os serolicos e serolicas eram estereótipos fundamentados em homens e mulheres que subiam nas posições sociais hierarquizadas do Portugal moderno, num movimento ascensional acompanhado do refinamento das aparências e de preocupações com a moda e a adequação aos lugares sociais paulatinamente conquistados. Conquista indevida, segundo o pensamento do autor:

Serolico, quem te deu tamanho bico? Responde: Quem me deu? Deu-me o Anticristo. Sim. ○ Anticristo é o que com seu pasto engorda os Serolicos do mundo. Ele é o alfaiate que corta a gala; ele o bufarinheiro, que vende a colônia; ele o inglês, que alcovita a peruca; ele o maroto, que vende os polvilhos, e ele o algibebe dos corpos humanos: ele com tudo aumenta, e com qualquer coisa engana $[\ldots] .60$

Os serolicos e serolicas da sociedade portuguesa teriam recebido "tamanhos bicos" do anticristo, figura relacionada ao apocalipse e ao fim dos tempos. Raphael Bluteau, em sua definição do termo, afirmou, apoiado na leitura de uma das epístolas de São João, que existiriam muitos anticristos no mundo: "todo aquele que nega o Padre Ełerno, e seu Divino Filho, e não crê em Jesus Cristo, é anticristo". ${ }^{61}$ A origem dos serolicos afirmada por Frei lucas leva a crer que o que fundamentaria a mobilidade social, seria algo contrário às leis da natureza e às divinas. A mobilidade social, em outras palavras, segundo o pensamento do religioso, não deveria existir.
59. DISCURSO..., v. 1, p. 141-142.

60. Id., v. 1, p. 143.

61. Bluteau, op. cit., v. 1, p. 402. 


\section{CONSIDERAÇÕES FINAIS}

Criados para veicular uma crítica aos usos da aparência como caminho para angariar reconhecimento no meio social, os estereótipos satíricos construídos por Frei Lucas de Santa Catarina carregavam matizes que revelavam uma problemática mais profunda que afetava a realidade social: a mobilidade social. O tema, velado em alguns de seus textos e tratado de maneira aberta em outros, esteve em parte considerável dos escritos reunidos no primeiro volume do Anatômico jocoso, textos que, na primeira metade do século XVIII, já circulavam de maneira intensa nos vários segmentos da sociedade portuguesa.

Segundo uma visão geral apreensível dessa obra, as ruas, igrejas e passeios dos espaços mais urbanizados do reino estavam repletos de sujeitos que encontravam nesses locais ambientes propícios à exibição. $\bigcirc$ trato de si dignificava a pessoa e a aparência era um elemento de grande importância para o processo de identificação social. Disso derivava a necessidade de manter a correspondência entre o ser e o parecer.

As possibilidades de afastamentos entre ser e parecer colocavam os indivíduos que prezavam pela boa aparência como meio de ostentar uma posição social de superioridade num emaranhado complexo de atitudes, comportamentos, combinações e formas de uso em constante processo de classificação. Não bastava possuir os artefatos indumentários que estivessem em moda; era necessário saber fazer deles o uso considerado e visto como correto. A distinção se fazia pela posse dos artefatos, por suas matérias-primas, bem como pelas maneiras de usar tais elementos materiais e de se portar durante seu uso.

As dinâmicas de diferenciação social por meio das aparências eram asseguradas pelos artefatos indumentários produzidos com matérias-primas nobres e luxuosas, pelos cortes das peças e modelos utilizados, bem como pelo seu estado de conservação. Tudo era considerado no interior de uma escala que classificava esses artefatos e os tornava pertinentes às categorias sociais. Peças ditas necessárias pela moda em sua combinação nas vestimentas dos indivíduos criavam o alicerce sobre o qual se assentariam o bom gosto e o refinamento. Nessas construções, os usos selavam os critérios para a classificação geral das aparências: não bastava ter, era necessário saber usar. E, como visto, nesses textos, tais entendimentos ou conhecimentos não poderiam ser provenientes da vontade dos indivíduos ou aprendidos por meio de estudo. Em vez disso, estariam associados à natureza de cada pessoa, variando de acordo com seu estado de nascimento. Toda uma visão naturalizada das hierarquias sociais embasava essas concepç̃es. E aqueles que 
partilhavam dessas concepções reagiam com desaprovação aos fenômenos de mobilidade que transpareciam nos trajes, adornos e trejeitos.

Os críticos, tais como Frei lucas, criavam por meio de seus textos e da construção das sátiras ferramentas que permitiam, senão reconhecer, ao menos desconfiar das aparências. As dissimulações poderiam ser identificadas por meio dos estados de conservação dos artefatos indumentários e pela forma de empenhálos sobre o corpo. Se por um lado as Turinas poderiam servir de cartilha aos elementos das camadas inferiores da escala social na construção e na manutenção de uma imagem a ser apresentada na sociedade, por outro poderiam ser índice para observar os indivíduos no espaço público, auxiliando no processo de classificação dos outros por meio do visual. A mobilidade social colocava em causa as hierarquias e tornava necessárias adaptações na leitura alheia para não errar no tratamento dispensado aos pares no meio social. Os textos de Frei Lucas de Santa Catarina constituíam quadros com caracterização abundante, que viabilizavam o reconhecimento de falsidades e artificialidades nas mínimas sutilezas do aparentar. Assim, além de provocarem o riso e, possivelmente, inibirem tais comportamentos em alguns de seus leitores ou ouvintes, essa produção tentava criar mecanismos que corroborassem a manutenção de um determinado modelo de sociedade rigidamente dividida em ordens.

O fenômeno da mobilidade social despertava a repulsa nos setores mais conservadores da sociedade. Consequentemente, a melhoria do trato de si quanto à imagem a ser apresentada nos diferentes espaços, como decorrência dessa mobilidade, gerava críticas ácidas. Os modelos de boa aparência criados pela nobreza eram desejados e seguidos por seus efeitos distintivos na sociedade e, por esses mesmos efeitos, eram repudiados quando incorporados por sujeitos sem condição nobre de nascimento. 


\title{
REFERÊNCIAS
}

\author{
FONTES IMPRESSAS
}

BLUTEAU, Raphael. Vocabulario portuguez \& latino: aulico, anatomico, architectonico... Coimbra: Collegio das Artes da Companhia de Jesu, 1712-1728. 8 v.

DISCURSO sobre as palavras do serolico berolico, quem te deu tamanho bico? In: Anatômico jocoso, que em diversas operações manifesta a ruindade do corpo humano, para a emenda do vicioso; Consta de várias obras em proza, que muitos copiaram pela grande estimação, e aplauso tributado por todo este Reino; as quais se expõem ao público para divertimento dos curiosos, e desejosos de ouvirem as Obras de tão famigerado autor. Pelo Padre Fr. Francisco Rey de Abreu Matta Zeferino. Tomo Primeiro. Lisboa: Na Oficina do Doutor Manoel Alvarez Solano, 1755. v. 1, p. 131-144.

ELOGIO do M. Tremendo Padre Mestre D. Relógio de Aragão, Conego extravagante das portas adentro detrás de S. Vicente de fora, junto a Santa Clara, à vista de Santa Monica, Presidente de uma Mesa de Piques, Provedor de odres, Provisor das adegas, Lente de Prima de uma Cadeira de espaldas, etc. In: Anatômico jocoso, que em diversas operações manifesta a ruindade do corpo humano, para a emenda do vicioso; Consta de várias obras em proza, que muitos copiaram pela grande estimação, e aplauso tributado por todo este Reino; as quais se expõem ao público para divertimento dos curiosos, e desejosos de ouvirem as Obras de tão famigerado autor. Pelo Padre Fr. Francisco Rey de Abreu Matta Zeferino. Tomo Primeiro. Lisboa: Na Oficina do Doutor Manoel Alvarez Solano, 1755. v. 1, p. 39-44.

SILVA, Antonio Moraes. Diccionario da lingua portuguesa: recompilado dos vocabularios impressos ate agora, e nesta segunda edição novamente emendado e muito acrescentado, por Antonio de Moraes Silva. Lisboa: Typographia Lacerdina, 1813. 2 v.

TURINA COTIDIANA e regra de viver para todo fiel faceira: Composta pelo Licenciado Nada Lhe Escapa, graduado em murmurações. Dirigida ao muy alto, e turinado senhor Fulano de Tal, Propagador das modas, Inventor das Turinas, Conservador das Faceiras, Espadachim dos quitós, Perna quebrada das bengalas, Rémora dos vestidos, Sanguessuga dos jantares, Carrapato de Lisboa, Cotidiana estaca dos Lausperenes, e Namorador extraordinário destes Reinos. Ano Presente. In: Anatômico jocoso, que em diversas operações manifesta a ruindade do corpo bumano, para a emenda do vicioso; Consta de várias obras em proza, que muitos copiaram pela grande estimação, e aplauso tributado por todo este Reino; as quais se expõem ao público para divertimento dos curiosos, e desejosos de ouvirem as Obras de tão famigerado autor. Pelo Padre Fr. Francisco Rey de Abreu Matta Zeferino. Tomo Primeiro. Lisboa: Na Oficina do Doutor Manoel Alvarez Solano, 1755. v. 1, p. 1-22.

TURINA FÊMEA. Universal disposição para o trato Feminino, e mulheril adorno. Dedicada ao senhor D. Toucador, Mestre dos Gabinetes, Olhador dos Espelhos, Compositor dos adornos, Vigilante Reparador dos concertos, Embaixador dos laços, e Penteador dos topetes mundanos. Autor: O doutor que Tudo Espreita. Ano Presente. In: Anatômico jocoso, que em diversas operações manifesta a ruindade do corpo humano, para a emenda do vicioso; Consta de várias obras em proza, que muitos copiaram pela grande estimação, e aplauso tributado por todo este Reino; as quais se expõem ao público para divertimento dos curiosos, e desejosos de ouvirem as Obras de tão famigerado autor. Pelo Padre Fr. Francisco Rey de Abreu Matta Zeferino. Tomo Primeiro. Lisboa: Na Oficina do Doutor Manoel Alvarez Solano, 1755. v. 1, p. 67-89. 
BOURDIEU, Pierre. A economia das trocas simbólicas. São Paulo: Perspectiva, 2009.

BOURDIEU, Pierre. Capital simbólico e classes sociais. Novos estudos CEBRAP, São Paulo, n. 96, p. 105-115, 2013. Doi: <https://doi.org/10.1590/S0101-33002013000200008>.

BRAGA, Isabel M. R. Mendes Drumond. O vestuário e a casa dos mercadores portugueses seiscentistas: simplicidade ou luxo? Semata, Santiago de Compostela, v. 21, p. 141-165, 2009.

BRAGA, Isabel M. R. Mendes Drumond. Das tendas dos mercadores têxteis portugueses: inquisição e cultura material nos séculos XVII e XVIII. Librosdelacorte.es, Madrid, v. 6, p. 185211, 2017. Disponível em: <https://bit.ly/3e0H55B>. Acesso em: 28 set. 2020. Doi: <https:// doi.org/10.15366/ldc2017.9.m6.009>.

CABETE, Susana Margarida Carvalheiro. A narrativa de viagem em Portugal no século XIX: alteridade e identidade nacional. 2010. Tese (Doutorado em Literatura Comparada) - Faculdade de Ciências Sociais e Humanas, Universidade Nova de Lisboa, Lisboa, 2010. Disponível em: <https://bit.ly/3gNfruA>. Acesso em: 5 out. 2020.

CALANCA, Daniela. História social da moda. São Paulo: Editora Senac, 2008.

COSTA, Ana Cecília Machado da. Erudição e utilitas na obra de Frei Lucas de Santa Catarina [1660 - 1740]. 2007. Dissertação (Mestrado em Literaturas Românicas) - Faculdade de Letras da Universidade do Porto, Porto, 2007.

DURÃES, Andrea. Grupos intermédios em Portugal (1600-1850): uma aproximação ao vocabulário social. Topoi, Rio de Janeiro, v. 14, n. 27, p. 318-343, 2013. Disponível em: <https:// bit.ly/3u4BH6R>. Acesso em: 23 set. 2020. Doi: <https://doi.org/10.1590/2237-101X014027005>.

FIADEIRO, Paula Cristina Neves. Ecos do Galateo: cortesania, comportamento e ética na literatura do Portugal moderno. 2007. Tese (Doutorado em Literatura) - Departamento de Línguas e Cultura, Universidade de Aveiro, Aveiro, 2007.

GIORGI, Arianna. Apariencia y movilidad social: el atuendo español em el siglo XVII. In: HENAJEROS LÓPEZ, Juan Francisco; IRIGOYEN LÓPEZ, Antonio. Escenarios de familia: trayectorias, estrategias y pautas culturales: siglos XVI-XX. Murcia: Editum, 2017. p. 455-461.

HESPANHA, António Manuel. A mobilidade social na sociedade de Antigo Regime. Tempo, Niterói, v. 11, n. 21, p. 121-143, 2006. Doi: <https://doi.org/10.1590/S1413-77042006000200009>.

LARA, Silvia Hunold. Fragmentos setecentistas: escravidão, cultura e poder na América portuguesa. São Paulo: Companhia das Letras, 2007. 
LOPES, Maria Antónia. Mulberes, espaço e sociabilidade: a transformação dos papéis femininos em Portugal à luz de fontes literárias (segunda metade do século XVIII). Lisboa: Livros Horizonte, 1989.

MADUREIRA, Nuno Luís. Ouro e prata: os gestos e os objetos na Lisboa antiga. Ler História, Lisboa, n. 20, p. 39-60, 1990.

MAGALHÂES, Joaquim Romero. Os nobres da governança das terras. In: MONTEIRO, Nuno Gonçalo; CARDIM, Pedro; CUNHA, Mafalda Soares da (orgs.). Optima pars: elites iberoamericanas do Antigo Regime. Lisboa: Imprensa de Ciências Sociais, 2005. p. 65-71.

MENESES, José Newton Coelho. Apresentação. Varia História, Belo Horizonte, v. 27, n. 46, p. 397-414, 2011. Disponível em: <https://bit.ly/3vymrQd>. Acesso em: 8 out. 2020.

MENESES, Ulpiano Toledo Bezerra. A cultura material no estudo das sociedades antigas. Revista de História, São Paulo, n. 115, p. 103-117, 1983. Doi: <https://doi.org/10.11606/issn.23169141.v0i115p103-117>.

MENESES, Ulpiano Toledo Bezerra. Apresentação. In: MARTINEZ, Claudia Eliane Parreiras Marques. Riqueza e escravidão: vida material e população no século XIX: Bonfim do Paraopeba, MG. São Paulo: Annablume, 2007. p. 13-16.

MENESES, Ulpiano Toledo Bezerra. Prefácio. In: CARVALHO, Vânia Carneiro de. Gênero $e$ artefato: o sistema doméstico na perspectiva da cultura material: São Paulo, 1870-1920. São Paulo: Edusp, 2008. p. 12.

MILLER, Daniel. Trecos, troços e coisas: estudos antropológicos sobre a cultura material. Rio de Janeiro: Zahar, 2013.

MIRANDA, Tiago C. P. dos Reis; FEITLER, Bruno. Apresentação: hierarquias e mobilidade social no Antigo Regime: os grupos intermédios no mundo português. Revista de História, São Paulo, n. 175, p. 15-22, 2016. Disponível em: <https://bit.ly/2PzH13e>. Acesso em: 20 set. 2018. Doi: $<$ https://doi.org/10.11606/issn.2316-9141.rh.2016.124066>.

NOGUEIRA, Carlos. Aspectos da literatura de cordel portuguesa. eHumanista, Santa Bárbara, v. 21, p. 195-222, 2012.

NORTON, Marta Pinha Neves Salazar. Espelho de vaidades: o peralta e a moda na literatura de cordel portuguesa, 1781-1789. 2000. Dissertação (Mestrado em Estudos Portugueses e Brasileiros) - Universidade do Porto, Porto, 2000.

PEDREIRA, Jorge Miguel Viana. Os homens de negócio da Praça de Lisboa de Pombal ao Vintismo (1755-1822): diferenciação, reprodução e identificação de um grupo social. 1995. Tese (Doutorado em Sociologia) - Faculdade de Ciências Sociais e Humanas, Universidade Nova de Lisboa, Lisboa, 1995. 
PEÑA DÍAZ, Manuel. La vida cotidiana en el mundo bispánico (siglos XVI-XVIII). Madrid: Abada, 2012.

REVEL, Jacques. Os usos da civilidade. In: ÁRIES, Phillipe; CHARTIER, Roger (orgs.). História da vida privada: volume 3: da Renascença ao século das Luzes. São Paulo, Companhia das Letras, 1991. p. 169-209.

ROCHE, Daniel. A cultura das aparências: uma história da indumentária (séculos XVII-XVIII). São Paulo: Editora Senac, 2007.

SANTOS, Maria José Moutinho dos. O luxo e as modas em textos de cordel da segunda metade do século XVIII. Revista de História, São Paulo, v. 9, p. 137-164, 1989.

SENNETT, Richard. O declínio do homem público: as tiranias da intimidade. Rio de Janeiro: Record, 2014.

SILVA, Luciana da. Aparências e sensibilidades: a indumentaria na Vila do Carmo (Mariana), 1693-1755. 2019. Tese (Doutorado em História) - Universidade Estadual de Campinas, Campinas, 2019.

SUCENA, Berta de Moura. Corpo, moda e luxo em Portugal no século XVIII. 2007. Dissertação (Mestrado em História) - Universidade de Lisboa, Lisboa, 2007.

VIGARELLO, Georges. História da beleza. Rio de Janeiro: Ediouro, 2006.

VIGARELLO, Georges. O limpo e o sujo: a higiene do corpo desde a Idade Média. Lisboa: Editorial Fragmentos, 1996.

Artigo apresentado em: 15/10/2020. Aprovado em: 19/02/2021.

\section{(cc) BY}

